\title{
MODELING OF SELF-HEALING MATERIALS USING NANOCONTAINERS
}

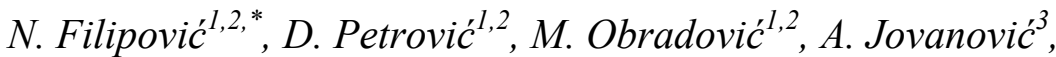

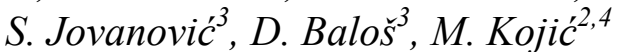 \\ ${ }^{1}$ Faculty of Mechanical Engineering, University of Kragujevac, Sestre Janjić 6, Serbia \\ ${ }^{2}$ Research and Development Center for Bioengineering, BioIRC, Kragujevac, Serbia \\ ${ }^{3}$ Risk-technologies, GmbH, Stuttgart, Germany \\ ${ }^{4}$ Methodist Hospital Research Institute, Houston, USA
}

\begin{abstract}
The surface defects of the material are difficult to detect and difficult to repair. A grand challenge in materials science is to design „smart“ synthetic system that can re-establish the continuity and integrity of the damaged area. Recent research of the nanocontainers with process of self-healing materials promises a good avenue for new smart nanocoating interfaces. We use two different modeling approaches, discrete and continuum, to investigate coating substrates that contain nanoscale defects with healing agents. The discrete modeling uses the Dissipative Particle Dynamics (DPD) method with usual three forces: repulsive, dissipative and random forces, as well as additional forces which bound healing agents to metal substrate. The continuum modeling uses Finite Element Method (FEM) with different diffusivity and fluxes. The initial results show what the necessary share is, in percentages, of the inhibitors in nanocontainers, to protect the metal surface which is treated with these healing agents. Further application of modeling coupled with data mining technology could help faster development of new active multi-level protective systems for future materials.
\end{abstract}

Keywords: self-healing material process, dissipative particle dynamics (DPD), finite element methods (FEM), nanocoating.

\section{INTRODUCTION}

Corrosion degradation of materials and structures is one of the important issues that lead to depreciation of investment goods. Two main approaches, an active and a passive one, are currently used for corrosion protection. The passive corrosion protection is achieved by deposition of a barrier layer preventing contact of the material with the corrosive environment [1].

Small size defects can appear on the surface of a material. Such defects have a substantial effect on the mechanical properties of material. To protect this material failure the coating systems are used on a wide range of engineering structures, from cars to aircrafts, from chemical factories to household equipment. The "self-healing" or "inhibition" are a relatively new terms in science of materials which means a self-recovery of initial properties of the material after destructive actions of external environment. There is an urgent demand for industrial applications to initiate development of an active healing mechanism for polymer coatings and adhesives [2].

In this study we presented two different modeling approaches, DPD and FEM for self-healing materials. We begin by describing the details of the nanocontainers healing concept, DPD and FEM methodology. We then discuss the effect of varying the nanocontainers fillings, particle-particle interactions, diffusivity parameter and the localization of the particles into the scratch. These findings provide guidelines for formulating nanocomposite coatings that effectively heal the surfaces through the self-assembly of the particles into the defects.

\section{METHODS}

\subsection{Nanocontainers healing concept}

The initial process of nanocontainer breaking starts at a random position where a crack occurred. The nanocontainer membrane is approximated by

${ }^{*}$ Corresponding author: fica@kg.ac.rs 
one layer of particles and particles inside the nanocontainers represent healing agents - inhibitors. We consider that nanocontainers are fixed in the coating layer (pretreatment or primer layer) as can be seen in Fig. 1.

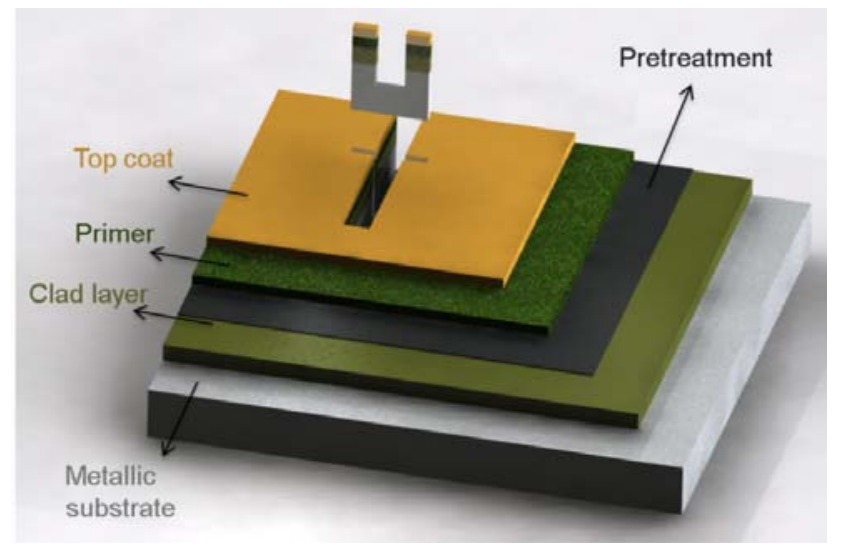

Figure 1. Model with nanocontainers in primer layer

Nanocontainers release the "self - healing" agent particles which are filling the space inside the crack in order to bond it and to protect crack from further propagation. We modeled a process of selfhealing using DPD method with additional spring force and surface wetting to attach healing agent particles to the damaged metal surface. The continuum model used the process of convective-diffusion for inhibitors binding to the substrate surface.

\subsection{DPD Model}

The coating layer with nanoscopic scratch can be modeled using molecular dynamics [2]. Another approach to this problem is a mesoscoping modeling using the DPD method $[3,4]$. Motion of each DPD particle (below in text referred to as "particle") is described by the following Newton law equation:

$m_{i} \dot{\mathbf{v}}_{i}=\sum_{j}\left(\mathbf{F}_{i j}^{C}+\mathbf{F}_{i j}^{D}+\mathbf{F}_{i j}^{R}\right)+\mathbf{F}_{i}^{e x t}$

where $m_{i}$ is the mass of particle " $i$ "; $\dot{\mathbf{v}}_{i}$ is the particle acceleration as the time derivative of velocity; $\mathbf{F}_{i j}^{C}, \mathbf{F}_{i j}^{D}$, and $\mathbf{F}_{i j}^{R}$ are the conservative (repulsive), dissipative and random (Brownian) interaction forces, that particle " $j$ " exerts on particle " $i$ ", respectively, provided that particle " $j$ " is within the radius of influence $r_{c}$ of particle " $i$ "; and $\mathbf{F}_{i}^{\text {ext }}$ is the external force exerted on particle " $i$ ", which usually represents gradient of pressure or gravity force as a driving force for the fluid domain [5]. The total interaction force $\mathbf{F}_{i j}$ (Fig. 2) between the two particles is

$\mathbf{F}_{i j}=\mathbf{F}_{i j}^{C}+\mathbf{F}_{i j}^{D}+\mathbf{F}_{i j}^{R}$

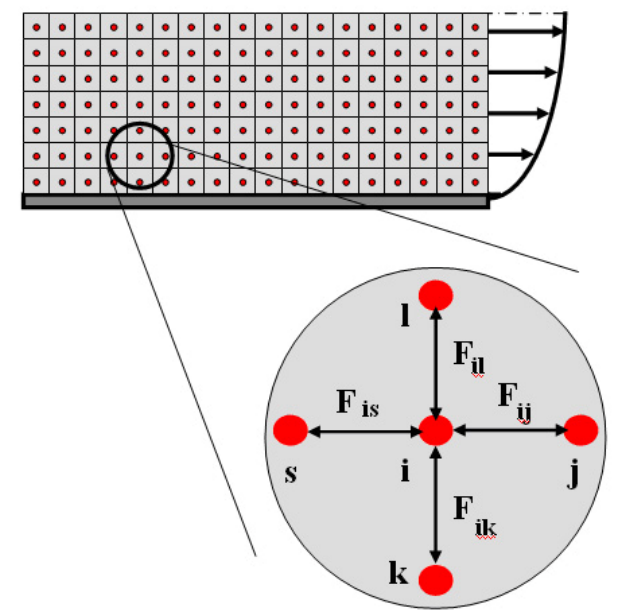

Figure 2. Interaction forces in the DPD method

The component forces can be expressed as [6] $\mathbf{F}_{i j}^{C}=a_{i j}\left(1-\frac{r_{i j}}{r_{c}}\right) \mathbf{r}_{i j}^{0}$

$\mathbf{F}_{i j}^{D}=-\gamma w_{D}\left(\mathbf{v}_{i j} \cdot \mathbf{e}_{i j}\right) \mathbf{r}_{i j}^{0}$

$\mathbf{F}_{i j}^{R}=\sigma w_{R} \xi_{i j} \mathbf{r}_{i j}^{0}$

In equation (3), $a_{i j}$ is the maximum repulsion force per unit mass, $r_{i j}$ is the distance between particles $i$ and $j, \mathbf{r}_{i j}^{0}=\frac{\mathbf{r}_{i j}}{r_{i j}}$ is the unit vector pointing in direction from $j$ to $i, \gamma$ stands for the friction coefficient, and $\sigma$ is the amplitude of the random force. Also, $w_{D}$ and $w_{R}$ are the weight functions for dissipative and random forces, dependent on the distance $r$ from the particle $i$; and $\xi_{i j}$ is a random number with zero mean and unit variance. The interaction force equals to zero outside the domain of influence, $r_{c}$ (cut radius), hence $F_{i j}=0$ for $r_{i j}>r_{c}$.

Further, for a DPD fluid system to have a Gibbs-Boltzmann equilibrium state, the following relation between the amplitudes of the weight functions of dissipative and random forces, $w_{D}$ and $w_{R}$, must apply:

$w_{D}=w_{R}^{2}$

Also the amplitude of the random force $\sigma$ is related to the absolute temperature $\mathrm{T}$,

$\sigma=\left(2 k_{B} T \gamma\right)^{1 / 2}$

where $k_{B}$ is the Boltzmann constant. The weight functions can be expressed in a form given as [5] 


$$
w_{D}=\left(1-\frac{r_{i j}}{r_{c}}\right)^{2}, \quad w_{R}=1-\frac{r_{i j}}{r_{c}}
$$

The particles used in this study represent both inhibition agents and surrounding coating material with different material characteristics. This was achieved by taking into account different repulsion force coefficient $\mathrm{a}_{i j}$. The additional interaction forces between particles of inhibition agents, which are placed in the primer layer and metal substrate particles, are added similarly as it was done in the model of thrombosis in $[7,8]$. These attractive forces are expressed as

$$
F_{a}=k_{s f}\left(1-\frac{L_{s f}}{L_{s f}^{\max }}\right)
$$

whereby $L_{s f}$ is the distance of the inhibition particle from the substrate, $k_{s f}$ is the effective spring constant, and $L_{s f}^{\max }$ is the maximum length of inhibition particle attractive domain.

\subsection{FEM model}

The mass transport process for inhibition system of coating is governed by convection-diffusion equation,

$$
\frac{\partial c}{\partial t}+v_{x} \frac{\partial c}{\partial x}+v_{y} \frac{\partial c}{\partial y}+v_{z} \frac{\partial c}{\partial z}=D\left(\frac{\partial^{2} c}{\partial x^{2}}+\frac{\partial^{2} c}{\partial y^{2}}+\frac{\partial^{2} c}{\partial z^{2}}\right)+q^{\text {wall }}
$$

whereby $c$ denotes the concentration of inhibitors; $v_{x}, v_{y}$ and $v_{z}$ are the velocity components in the coordinate system $x, y, z$; and $D$ is the diffusion coefficient, assumed to be constant, of the transported material; and $q^{\text {wall }}$ is flux of the binding process for inhibitors which adhere on the substrate surface. Similar concept is used for calculation of the volume of inhibitors which are possible to diffuse on the scratch surface. Diffusivity coefficient and wall binding flux are the fitting parameters in FEM model. The drawback of continuum approach is that particle-particle interaction cannot be modeled whereas the advantage is in the fact that it is possible to model a large substrate area.

\section{RESULTS}

\subsection{DPD model results}

The primer layer is represented by green particles, while inhibitors are shown as red particles (see Fig. 3). The material is scratched and it should be protected; the scratched area is represented by grey particles. Water which enters the scratch is modeled by surrounding light blue particles.

Graphic interface for modeling by DPD method, with input parameters that can be changed using dialog window, is shown in Fig. 4.

It is assumed that the external force acts on all particles. User can specify a DPD domain by defining a number of particles in $\mathrm{X}$ and $\mathrm{Y}$ directions. The basic material DPD constants: viscosity friction and repulsive force coefficient, are also prescribed. An additional repulsive force coefficient is given for inhibition particles in order to keep them close and direct them into the surrounding structural matrix which contains simple DPD particles, like primer and scratch particles.

Geometrical parameters of the model are marked in Fig. 1. A scaled model was used for simulation due to a large number of particles in the real model.

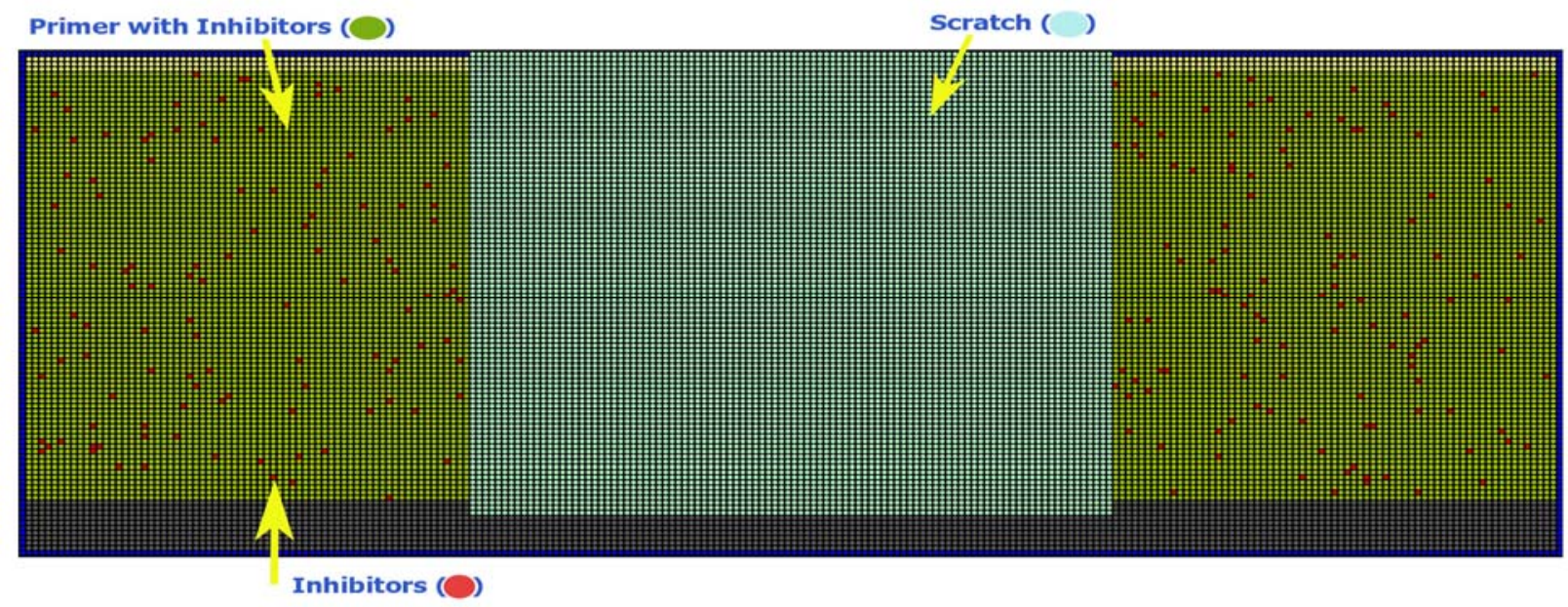

Figure 3. Model of material protection using inhibitors in the primer layer 


\begin{tabular}{|c|c|c|c|c|c|c|c|}
\hline Delta T: & 0.002 & Gamma: 4.5 & Rep, force coefficient: & 8 & Rep. force coefficient 2: & 500 & Test \\
\hline Ext. force: & 0.4 & Step average: 1000 & Total steps: & 100000 & Density of nanocontainers (\%): & 2 & 4 \\
\hline Division U: & 240 & Division V: 100 & $\nabla$ Include random force & & Nanocontainer diameter $(\mu \mathrm{m})$ : & 0.1 & Number of calculations \\
\hline Crack width $(\mu \mathrm{m})$ : & 63 & Crack height $(\mu \mathrm{m}): 58$ & Substrate height $(\mu \mathrm{m})$ : & 5 & Nanocontainer thickness $(\mu \mathrm{m})$ : & 0.1 & 1 \\
\hline Cladding height ( $\mu \mathrm{m})$ & 0 & Pretreatment height $(\mu \mathrm{m} \quad 0$ & Primer height $(\mu \mathrm{m})$ : & 54 & Top coat height $(\mu \mathrm{m})$ : & 2 & $\square$ Load random number \\
\hline \multicolumn{2}{|c|}{ Calculation Run } & Show results & \multicolumn{2}{|l|}{ Run/Stop animation } & & & \\
\hline
\end{tabular}

Figure 4. Dialog of the input parameters interface for a DPD modeling. DeltaT is time step for DPD simulation; Ext. force is the external force which acts in Y direction on all particles to produce motion; Division $U$ is the total number of particles in $X$ direction at initial time; Division $V$ is the total number of particles in Y direction at initial time; Gamma is the viscosity friction coefficient used in DPD equations; Step average is the total number of steps for writing results for animation; Total steps is the total number of time steps for the entire modeling period; Rep. force. coefficient is the repulsive force coefficient used for repulsive force for simple DPD particles; Rep. force. coeff. 2 is the repulsive force coefficient used for the repulsive force between inhibition particles; Include random force checking button is used for including/excluding random force in a DPD calculation; Density of Nanocontainers means percent of inhibition particles in the primer layer; Calculation button starts the program execution; Run/Stop animation button is used to start/stop animation which is obtained from the DPD calculated results.

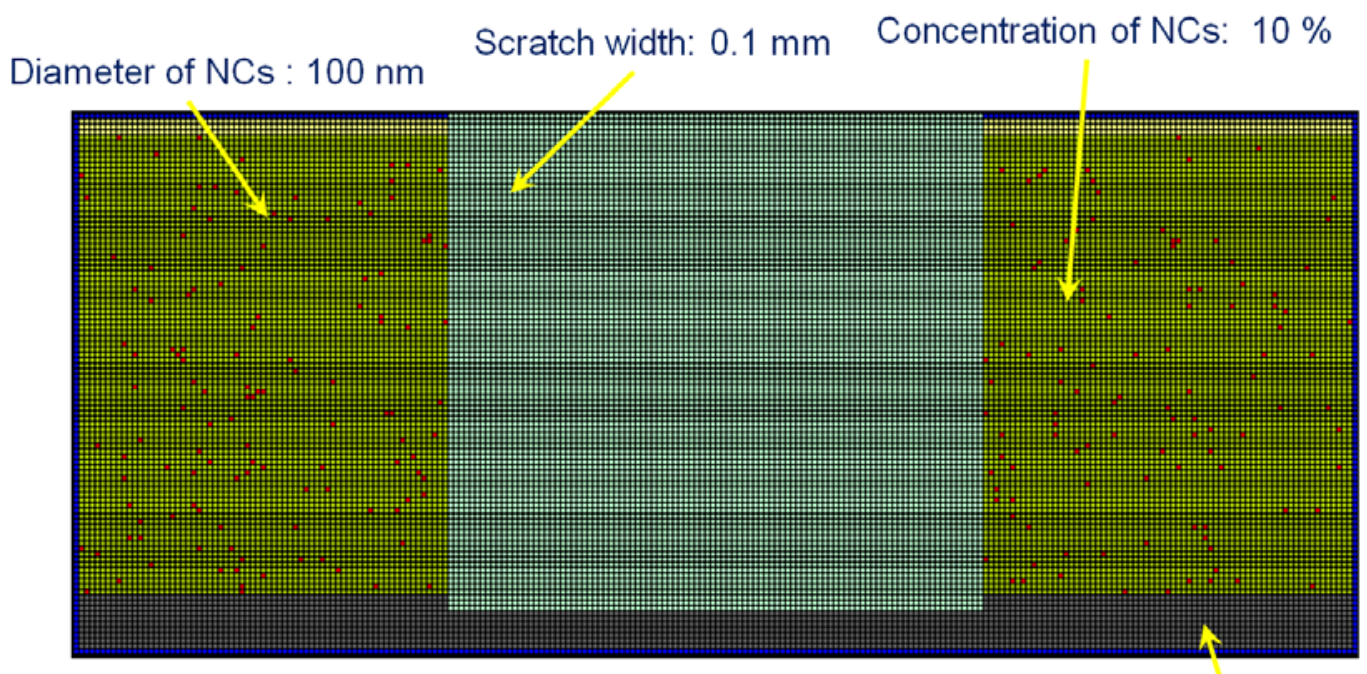

Metal substrate

Figure 5. Initial state and dimensions of a real model

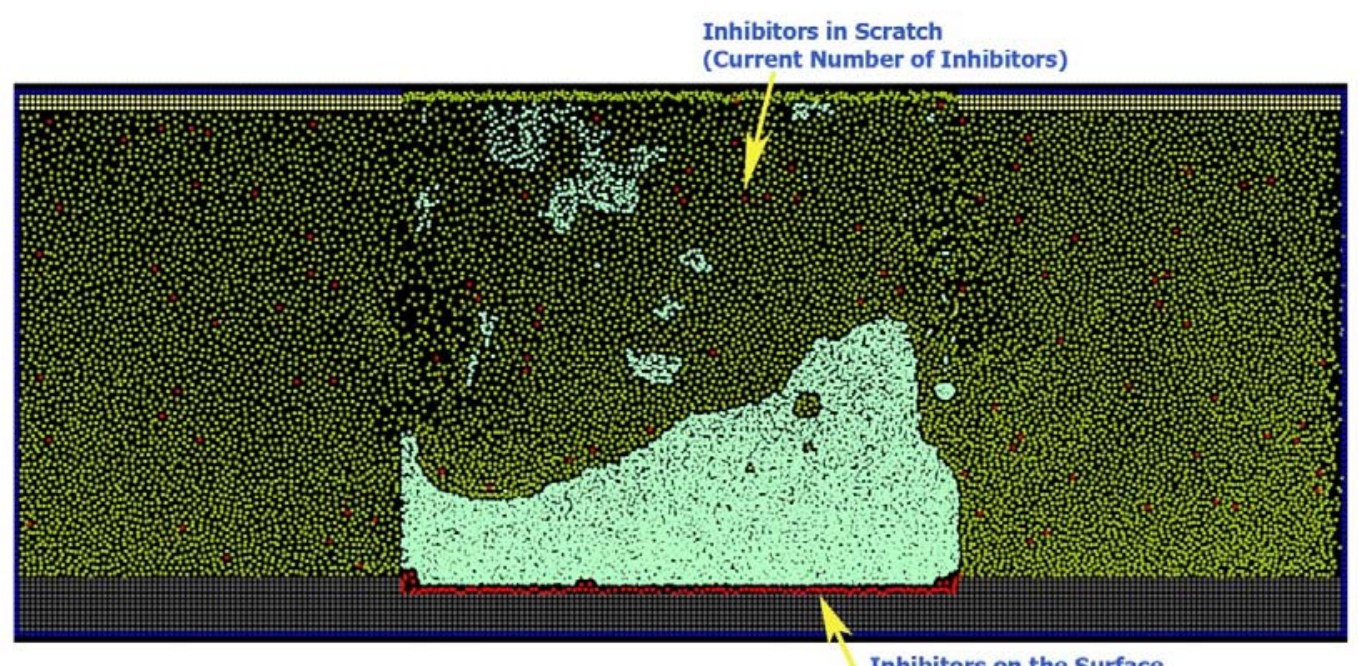

Inhibitors on the Surface

Figure 6. The DPD model after 100000 time steps (200s). Red particles represent the inhibition particles, green particles make primer layer, grey particles (substrate) are considered to be fixed in space domain. The surrounding particles are shown with light blue color and represent the fluid 
In the process of primer protection when the scratch occurred, the inhibitors in the primer layer start to interact with the surrounding particles and slip through the scratch on the metal substrate. For pure protection of metal substrate it is necessary to cover surface with one layer of inhibitors whose diameter is about $1 \mathrm{~nm}$. During the process of protection, inhibitor particles interact with primer and fluid particles, but with different repulsive force coefficient ("Rep. force coefficient" and "Rep. force coefficient 2", Fig. 4). Additional spring force was used (equation 7) to connect inhibition with metal substrate particles, so that the inhibitors particles are attached to the walls of the crack.

The first DPD model, with inhibitors in the primer layer, consists of a $2 \mathrm{D}$ rectangle crack do- main with the depth of $0.1 \mathrm{~mm}$. Total number of DPD particles was $24000(240 \times 100)$ and the model is scaled four times. The total number of time steps for simulation was 100000 .

A real scenario of realizing inhibition agents is to assume particle motion inside the crack domain and some surrounded area.

We investigated substrate surface coverage and the number of inhibitors in the primer needed to protect damaged material and repair it completely.

We tested metal coverage with different percent of inhibitors in the primer: $10 \%, 15 \%$ and $20 \%$. The computed results for the current number of inhibitors in the crack and percentage of covered damaged surface after 200s are given in Fig. 7 and Fig. 8.

\section{Current Number of Inhibitors vs. Time}

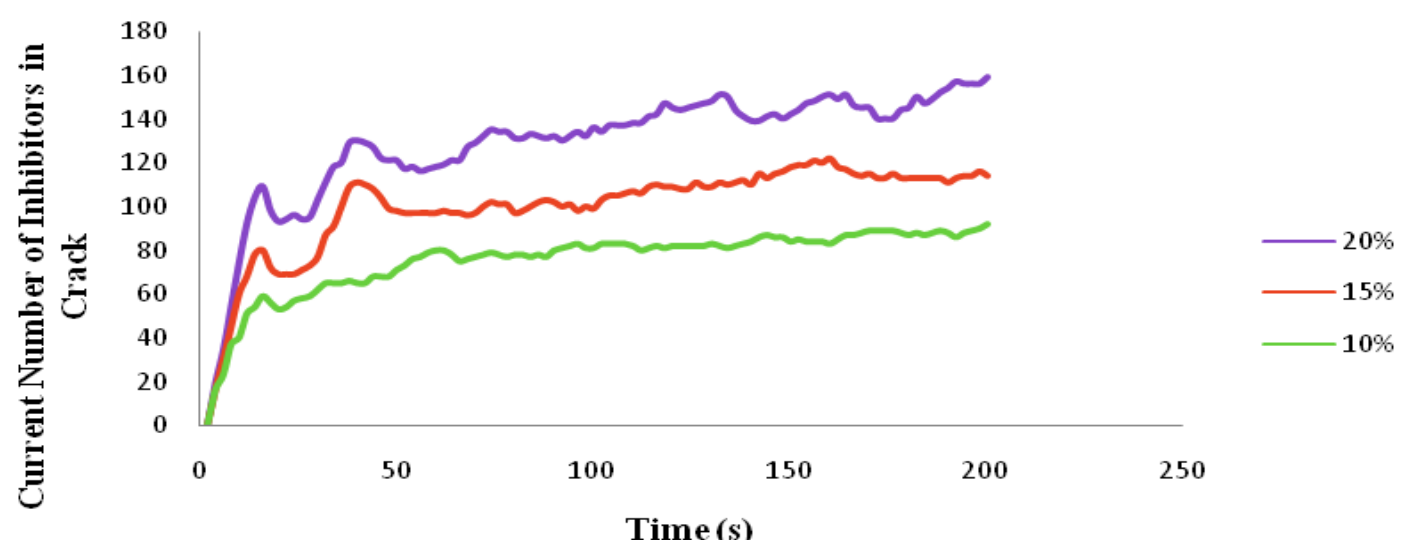

Figure 7. Increase in number of inhibitors on the metal surface over a time period obtained by a simple 2D analysis, for three percentage values of inhibitors in the primer: $10 \%, 15 \%$ and $20 \%$. Total time steps for DPD calculation was 100000

\section{Percent of Covered Surface vs. Time}

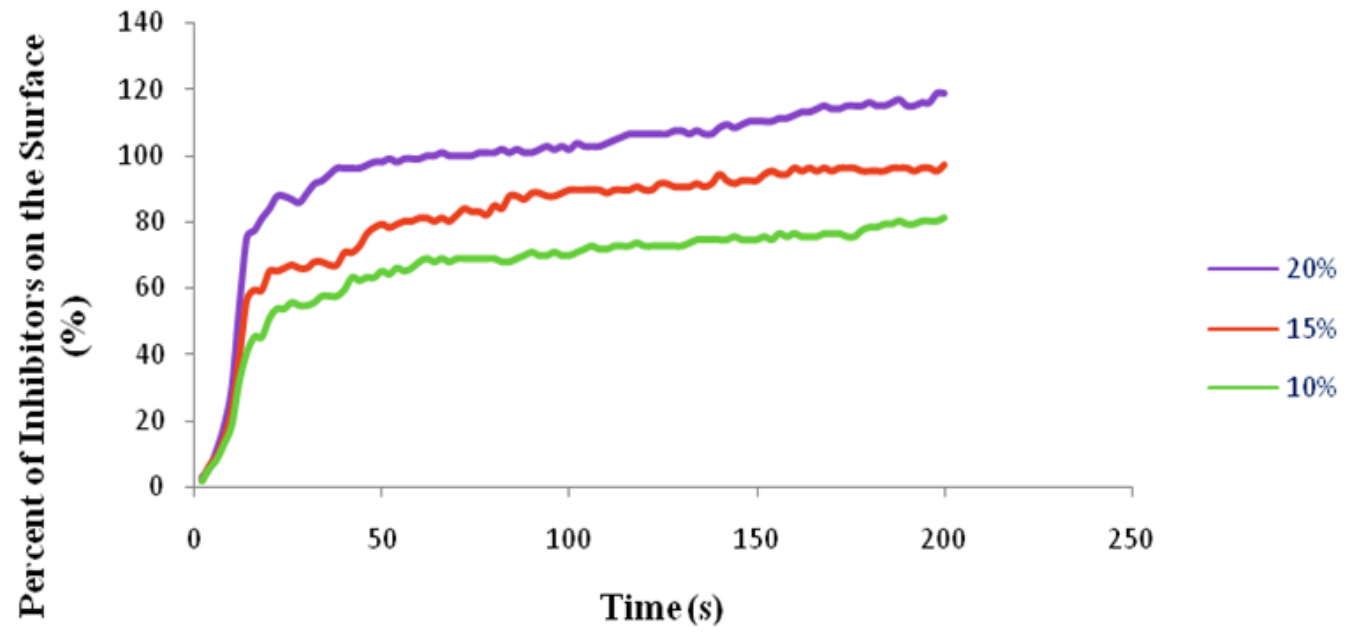

Figure 8. Percentage of inhibitors particles on the metal surface over a time period, for three percentage values of inhibitors in the primer: $10 \%, 15 \%$ and $20 \%$ 
For the second DPD model, with nanocontainers in the primer layer, we also used a scaled model, shown in Fig. 9.

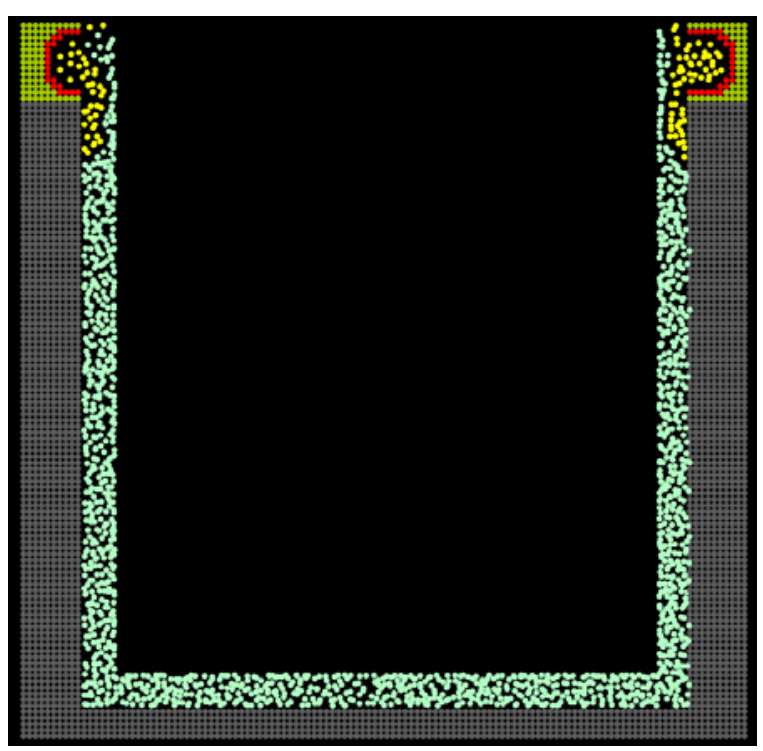

Figure 9. Scaled model with nanocontainers in the primer layer

In the second model we investigated the number of nanocontainers necessary to completely cover a certain specified surface, and the volume percentage of inhibitors in the nanocontainers. The production of nanocontainers and inhibitors is too expensive and it is needed to precisely establish minimum percentage of inhibitors in the nanocontainers for full protection of the treated material.

\subsection{FEM results}

The continuum model consists of mesh size of $30 \times 30,000=900,0003 \mathrm{D}$ finite elements where inhibitors are randomly prescribed as the influx boundary conditions. The scratch dimension is $0.1 \times 100$ $\mathrm{mm}$, the primer layer is $4000 \mathrm{~nm}$, nanocontainer diameter is $400 \mathrm{~nm}$. The percentage of inhibitor inside nanocontainers is $20 \%$ and the percentage of nanocontainers in the primer or pre-treatment layers is $10 \%$. The convection velocity is assumed to be zero due to dominant diffusion process. The binding flux was prescribed to be unit which depends on mechanical property of scratch, with no water inclusion on the surface. Computed results during the time period of $20 \mathrm{~h}$ of inhibition process are shown in Fig. 10. It can be seen that almost full $100 \%$ coverage is achieved within $10 \mathrm{~h}$.

Distribution of inhibitors on the scratch surface for time $=6 \mathrm{~h}$ is presented in Fig. 11. The inhibitors fluxes are randomly distributed along the plate, which causes higher coverage near these plate sides.

Space and time distribution of inhibitors on the scratch surface is shown in Fig. 12.

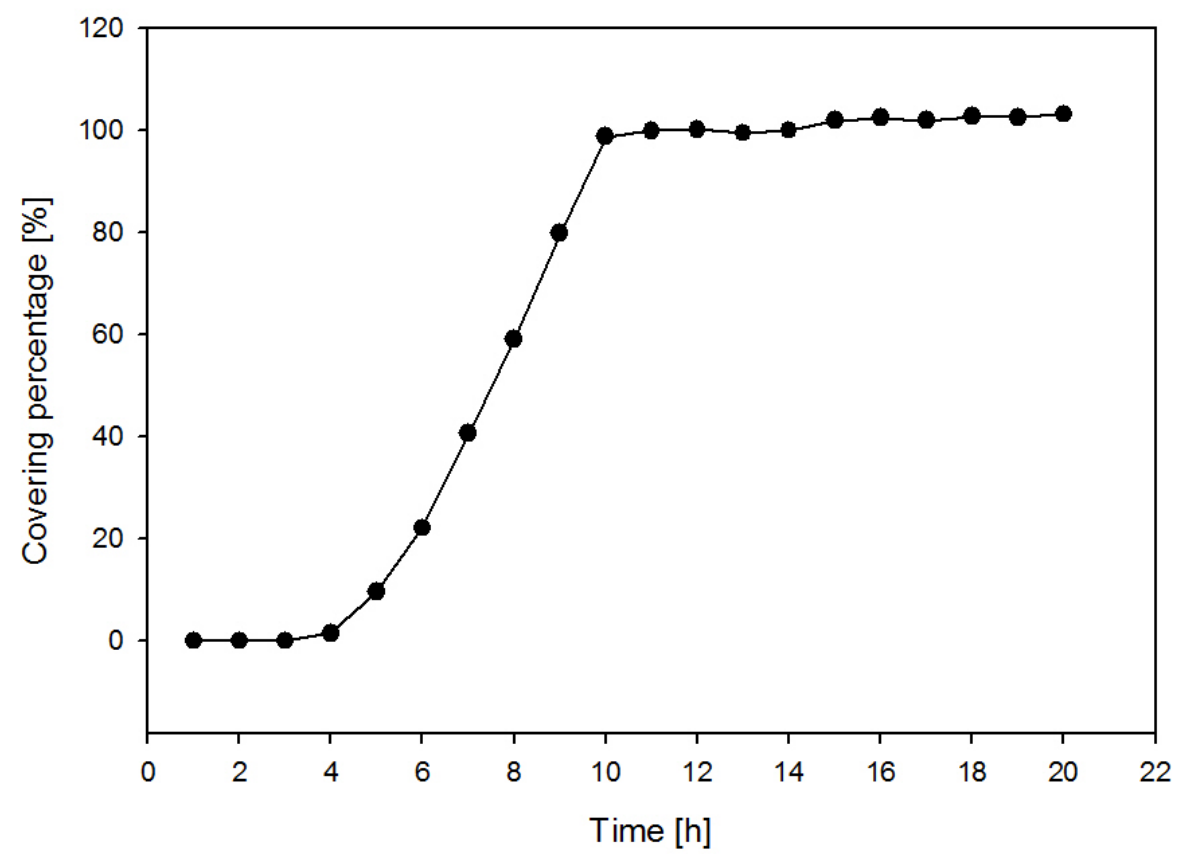

Figure 10. Cover percentage of the inhibitors on the substrate surface during time (FEM model) 


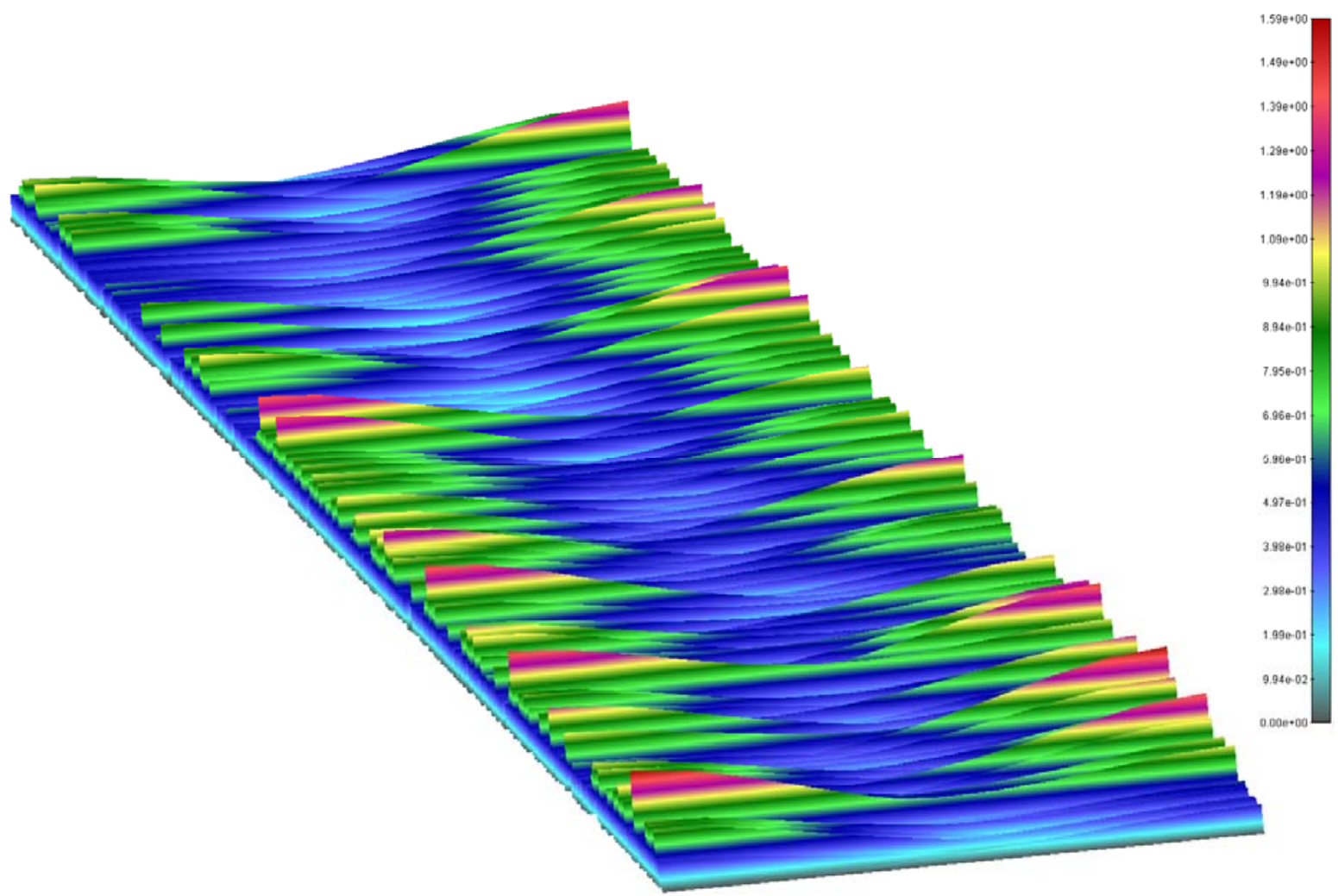

Figure 11. Distribution of inhibitors on the scratch surface for $t=6$ h. The width of the scratch is $0.1 \mathrm{~mm}$ and the length is $100 \mathrm{~mm}$

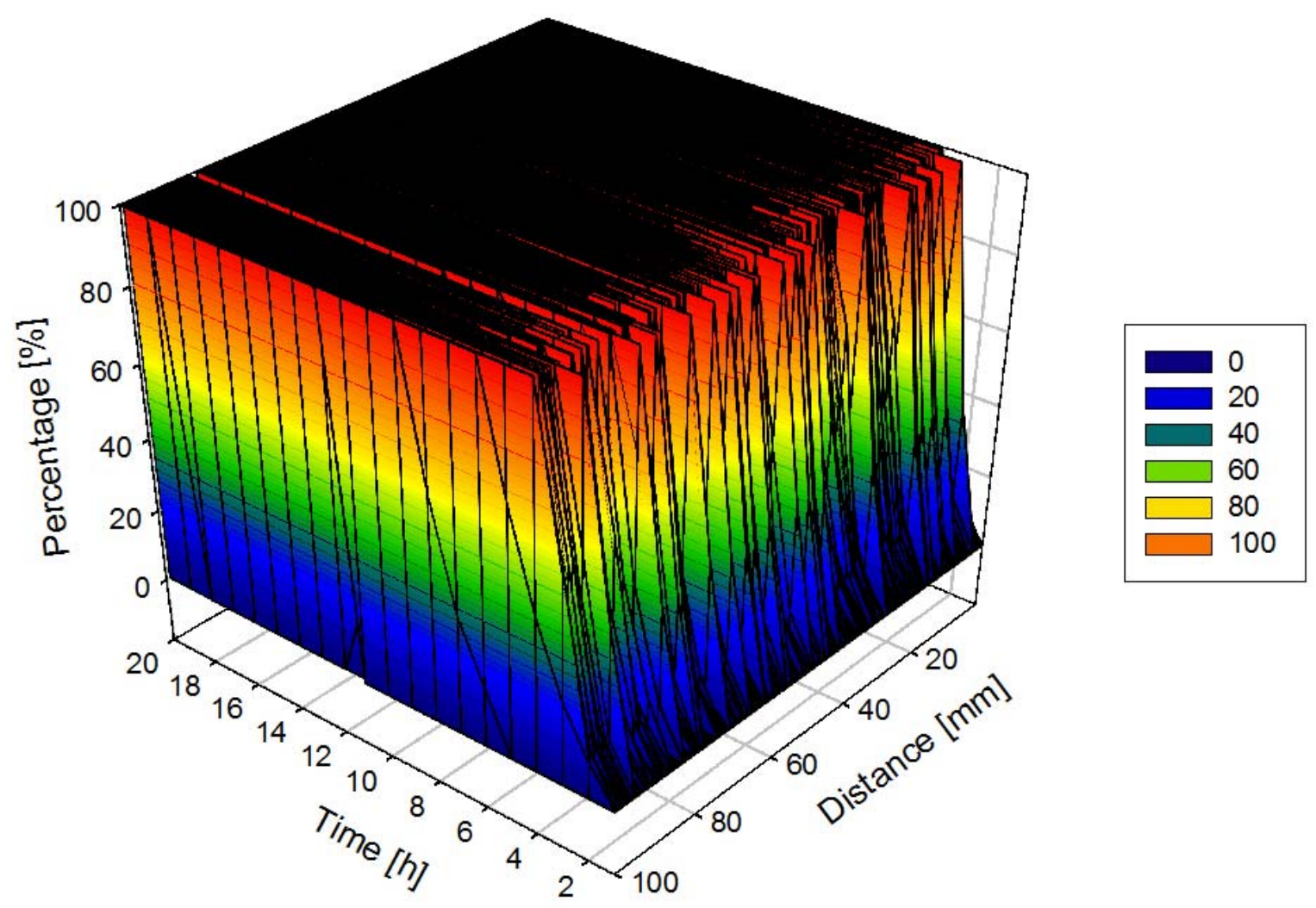

Figure 12. Space and time distribution of inhibitors on the scratch surface. The width of the scratch is $0.1 \mathrm{~mm}$ and the length is $100 \mathrm{~mm}$ 


\section{CONCLUSIONS}

In this study we used DPD and FE computer modeling methods to provide guidelines for designing self-healing systems. Our study has shown that it was sufficient to have $20 \%$ inhibitors in the primer layer with $10 \%$ of nanocontainers to completely protect the damaged material. Time for coverage can be fitted by employing real experimental data. By changing the input parameters it was possible to reduce this percentage, but not significantly. With these two methodologies we created new hybrid modeling methods that integrate fluid dynamics, structural mechanics, chemical reactivity, and phase transitions.

Future work will include design of multiple nanocontainers with assumed "density" in the given regions. We will also analyze combining of this modeling and a data mining technology, which could help faster development of new active multi-level protective systems for future industrial materials. Progress in this field can greatly facilitate fabrication of the next generation of adaptive materials which can self-heal themselves before any catastrophic failure occurs.

\section{ACKNOWLEDGEMENT}

This research was supported by Ministry of Science in Serbia, ON174028, III41007 and FP7 MUST project NMP3-LA-2008-214261.

\section{REFERENCES}

[1] M. L. Zheludkevich, D. G. Shchukin, K. A. Yasakau, K. Mohwald, and M. G. S. Ferreira, An- ticorrosion Coatings with Self-Healing Effect Based on Nanocontainers Impregnated with Corrosion Inhibitor, Chem. Mater. 19 (2007) 402-411.

[2] S. Tyagi, J. Y. Lee, G. A. Buxton, C. A. Balazs, Using Nanocomposite Coatings To Heal Surface Defects, Macromolecules 37 (2004) 9160 $-9168$.

[3] N. Filipović, D. J. Ravnić, M. Kojić, S. J. Mentzer, S. Haber, A. Tsuda, Interactions of Blood Cell Constituents: Experimental investigation and Computational Modeling by Discrete Particle Dynamics Algorithm, Microvascular Research 75 (2008b) 279-284.

[4] R. D. Groot and P. B. Warren, Dissipative particle dynamics: Bridging the gap between atomistic and mesoscopic simulation, J. Chem. Phys. 107(11), (1997) 4423-4435.

[5] K. Boryczko, W. Dzwinel, D. Yuen, Dynamical clustering of red blood cells in capillary vessels, J. Mol . Model 9 (2003) 16-33.

[6] N. Filipović, M. Kojić, A. Tsuda, Modeling thrombosis using dissipative particle dynamics method, Phil Trans Royal 366 (2008a) 3265-3279.

[7] P. J. Hoogerbrugge and J. M. V. A. Koelman, Simulating microscopic hydrodynamic phenomena with dissipative particle dynamics, Europhys. Lett. 19 (1992) 155-160.

[8] A. Jovanović and N. Filipović, Innovative modelling methods in damage assessment: application of dissipative particle dynamics to simulation of damage and self-healing of polymer coated surfaces, J. Theoretical and Applied Mechanics 44 (2006) 637-648.

\section{МОДЕЛИРАЬЕ САМОВЕЗУЈУЋИХ МАТЕРИЈАЛА КОРИШЋЕЬЕМ НАНОКОНТЕЈНЕРА}

Сажетак: Површинске дефекте у материјалу је тешко открити и санирати. Велики изазов у науци о материјалима је дизајн „паметних“ синтетичких система који могу да поново изграде континуитет и интегритет оштећене области. Недавна истраживања наноконтејнера са процесом самовезивања материјала обећавају нови пут за нове паметне нанопокривајуће заштите. Користимо две методе, дискретно и континуално моделирање, за истраживање покривања површина са самовезујућим материјалима које садрже оштећења на нивоу наноскале. Дискретна метода овде употребљена је „дискретна честична динамика“ у којој су коришћене уобичајене три силе: одбојна, вискозна и случајна, као и додатна сила везивања за металну површину. Континуум метода је метода коначних елемената са различитом дифузијом и флуксевима. Резултати показују колико је инхибитора у процентима потребно да буде у оквиру наноконтејнера да би могло доћи до потпуног покривања металне површине са овом мето- 
дом самовезивања. Будућа примена моделирања ће укључити и data mining технологију која може убрзати развој нових вишеслојних заштитних система за материјале у будућности.

Кључне речи: самовезивни процеси у материјалу, дискретна честична динамика, метод коначних елемената, нанопокривање.

$\cos 80$ 